\title{
Provision of curriculum model of student life skills at primary schools of Iran
}

\section{Provisión de un modelo curricular de habilidades para la vida de los estudiantes en las escuelas primarias de Irán}

\author{
Behzad Ghabakhlou \\ Teacher of Education and Cultural Organization, Urmia, Iran \\ ORCID: https://orcid.org/0000-0001-6499-2350 \\ Hassan Ghalavandi \\ Associate Professor, University of Urmia, Iran \\ ORCID: https://orcid.org/0000-0003-3552-4958 \\ Alireza Hosseinpour \\ Assistant Professor, University of Urmia, Iran \\ ORCID: https://orcid.org/0000-0002-5835-8449
}

Received 09-08-20 Revised 10-10-20

*Correspondence

Email: ghabakhlou@ aftermail.ir
Accepted 12-12-20 On line 03-10-21

Cite as:

Ghabakhlou, B., Ghalavandi, H., \& Hosseinpour, AR. (2021). Provision of curriculum model of student life skills at primary schools of Iran. Propósitos y Representaciones, 9 (SPE3), e1124. Doi: http://dx.doi.org.10.20511.pyr2021.v9nSPE3.1124 


\section{Summary}

This research seeks to answer the question about the appropriate model of student life skills at primary schools. A comprehensive questionnaire is designed relying on the academic and industrial experts, the research background and theoretical principles in order to test the hypotheses. The reliability of questionnaire is approved through Cronbach's alpha coefficient (0.70). The research results cover the prioritization and importance of indices associated with student life skills, antecedents and consequences, and their tasks. The need for education and establishment of this skill improves the relations in learning. This is can facilitate the teachinglearning process due to the today's widespread and growing changes in the content of textbooks, structure, etc. On the one hand, it can largely overcome the educational challenges between parents, teachers and school. On the other hand, it can reduce learning costs. These costs include the training time in the classroom, tutor, regulated teaching methods, reduced purchase of poorquality educational books, etc. These skills can also protect students from imposed teaching damages such as meaningful learning through repetition and practice. Furthermore, these skills enable the school principals to have higher accuracy and quality in their tasks such as educational supervision, control and decision-making, and the intra and extra-school communications. From principals' perspective, the self awareness has the higher rank than other components. From teachers' perspective, the scientific and technological skills have higher rank than other components; and from principals' perspective, the training time has better rank. Moreover, the teachers think that the personal factors have better ranks. Among the components, the life skill has higher rank.

Keywords: Curriculum, student life skills, antecedents and consequences, prioritization, teachers, principals

\section{Resumen}

Esta investigación busca dar respuesta a la pregunta sobre el modelo apropiado de habilidades para la vida de los estudiantes en las escuelas primarias. Se diseña un cuestionario completo basándose en los expertos académicos e industriales, los antecedentes de investigación y los principios teóricos para probar las hipótesis. La fiabilidad del cuestionario se aprueba mediante el coeficiente alfa de Cronbach $(0,70)$. Los resultados de la investigación cubren la priorización e importancia de los índices asociados con las habilidades para la vida de los estudiantes, antecedentes y consecuencias, y sus tareas. La necesidad de educación y el establecimiento de esta habilidad mejora las relaciones en el aprendizaje. Esto puede facilitar el proceso de enseñanza-aprendizaje debido a los cambios cada vez más generalizados y generalizados en el contenido de los libros de texto, la estructura, etc. Por un lado, puede superar en gran medida los desafíos educativos entre padres, maestros y escuela. Por otro lado, puede reducir los costos de aprendizaje. Estos costos incluyen el tiempo de capacitación en el aula, el tutor, los métodos de enseñanza regulados, la compra reducida de libros educativos de mala calidad, etc. Estas habilidades también pueden proteger a los estudiantes de los daños de la enseñanza impuestos, como el aprendizaje significativo a través de la repetición y la práctica. Además, estas habilidades permiten a los directores de escuela tener una mayor precisión y calidad en sus tareas, como la supervisión, el control y la toma de decisiones educativas, y las comunicaciones intra y extraescolares. Desde la perspectiva de los directores, la autoconciencia tiene un rango más alto que otros componentes. Desde la perspectiva de los docentes, las habilidades científicas y tecnológicas tienen un rango más alto que otros componentes; y desde la perspectiva de los directores, el tiempo de capacitación tiene mejor rango. Además, los profesores piensan que los factores personales tienen mejor rango. Entre los componentes, la habilidad para la vida tiene un rango más alto.

Palabras clave: Plan de estudios, habilidades para la vida de los estudiantes, antecedentes y consecuencias, priorización, maestros, directores 


\section{Introduction}

The today's human is faced with numerous challenges due to the life complexity, and the extent and speed of changes; and these challenges will be pronounced in the upcoming century (Ahfar, 2012). In this regard, the mental health of community is directly affected by its members' mental health. If a person has addiction, mental illness, personal, career and family problems, etc. endangering his mental health, the mental level of whole society will be reduced (Adib, 2006). In the meantime, the life skills training make the person ready to overcome tensions and difficulties ahead as this is the individual and society demand. Life skill training for students has been emphasized by a lot of teachers and educational experts. For instance, John Dewey believes that the education aims to prepare people for self-determination, and like any other learning, this learning should be practically done.

Given the importance of life skills learning to deal with everyday problems, and its impact on the improvement of individual and social life as well as the emphases on this issue, it should be taken into account in the education process. In this regard, a part of official school curricula in most of the educational systems has been dedicated to teaching these skills (Esmaeilzadeh, 2012). The ideal and curriculum objectives of the Iranian educational system have also explicitly or implicitly emphasized on the examples of life skills education. Therefore, the necessity for teaching such these skills is also strongly felt.

The educational system of Iran does not have an integrated curriculum for life skills training covering all aspects and elements of curriculum based on student, community, etc. needs. The welfare and rehabilitation organization was responsible for life skills training, but it was abandoned after a few years due to lack of attention to philosophical, social, and psychological principles in development of curriculum in this field. Nowadays, the life- student skills training is limited to Keramat plan which has not been successful in practice and its programs are experimental due to the lack of theoretical framework which has not been unfortunately studied accurately and because of the mere attention to some principles of curriculum including the sociology and philosophy and ignoring the life and technological principles of curricula (Ramasht and Farshad, 2004).

However, the development of a curriculum model for student life skills can create and improve social and personal development skills in students. On this basis, the students, who are trained on the basis of this model, will be able to do the group actions, learn better and take the responsibility for their own actions. They will learn the ways of effective communication and be able to communicate with their peers, use peaceful methods to solve their dispute, and accurately examine and criticize the social values and norms. These students will be familiar with their national heritage, and will protect their environment. They will also have higher resilience to problems.

The life skills refer to the practical ability and skills leading to positive and adaptive behavior and applied for sense of achievement, empowerment and happiness in everyday life. The educational objectives of these skills can be extracted from everyday needs and requirements (Esmaeilzadeh, 2012). The World Health Organization (WHO) has introduced ten skills as the basic life skills. These ten skills have been also considered as the basic life skills by UNICEF and UNESCO. These skills include the skills of self-awareness, empathy, effective communication skills, anger management, ability to establish and maintain effective interpersonal skills, daring behavior, problem solving, coping with stress, decision-making, creative thinking skills (WHO, 2006).

Given the importance of life skills to deal with daily life problems and the impact of relevant education on the health, mental health, academic achievement and generally the personal and social life improvement as well as the important roles of schools in preventing the social damages, learning and improvement of mental health, there is a need for attention to education process, but unfortunately this gap continues and the education system of Iran has been limited to provision of information and promotion of students' knowledge level and has not take the continuous and inclusive effort to deal with the adulthood challenges and requirement. 
Moreover, the conducted studies suggest that the life skills training has not been seriously considered in practice; and the students' levels of life skills achievement indicate the teachers' familiarity with skills, and its deficiency or absence. Gorman (2005) also argues that all research and plans in the field of life skills mainly focus on drugs and risky behavior, and do not pay attention to other skills. The variables such as the mental health, methods of coping with stress, and moral and spiritual health variables have also been taken into account in local studies (Khosravi and Ebrahimi, 2004). Despite the fact that the impressive and effective measures have not been taken so far, the implementation of this important issue has failed to define, explain and implement the special student skills as basic and input student skills, and reach the full richness in terms of theoretical principles. On this basis, this study seeks to introduce an appropriate model of student life skills at elementary school.

\section{Methodology}

This research is among the applied studies since it seeks to design an appropriate model for student life skills. Furthermore, this study is put in the "explanatory mixed studies" group in terms of data collection method. Therefore, the qualitative data was first collected and this led to the identification of multiple aspects of phenomenon and facilitated development of a conceptual model. The research tool was then built based on the results of qualitative data, and the quantitative data was collected to make the generalizability of findings possible. In general, the mixed method is selected for this study because of the following reasons: 1) obtaining more evidence to better understand the student life skills, 2) lack of an appropriate model of student life skills, and 3) the need for utilization of experts' views in designing the student life skills model.

\section{Qualitative research phase}

The qualitative phase was on the agenda using qualitative interviews with experts who had sufficient knowledge about student life skills. The interviews continued until different and latent aspects and components of student life skills phenomenon were identified and described and reached theoretical saturation. This study used the semi-structured interviews with experts in order to identify the components and factors affecting the student life skills. The statistical population consisted of faculty members as the professionals in this field, and principals and authorities who potentially had the highest information about student life skills. The sample size was according to the saturation level in qualitative phase; hence, the snowball sampling method was in addition to purposive sampling. Finally, 24 faculty members, school principals and teachers were interviewed in the field of student life skills. Validity and reliability of qualitative research phase were obtained based on the criteria namely the reliability or credibility, investigation by members (interviewees), triangulation of data sources, analysis of negative cases, and transferability.

\section{Quantitative research phase}

The descriptive research method is the most suitable method in quantitative phase of this research. Therefore, an appropriate model of student life skills can be provided through descriptive research method. In quantitative phase of research, we sought to design a quantitative tool based on the conceptual model resulting from identified components and indices, and widely use among the selected samples, thereby achieve an appropriate model of student life skills. The statistical population of this research in the quantitative phase consisted of all teachers and principals in Department of Education in counties of Tehran Province.

Sampling formula by Levy \& Lemeshow (2002) was used to determine the sample size. The process of sample size determination is presented as follows.

$n \geq \frac{z^{2} N V_{X}^{2}}{(N-1) \varepsilon^{2}+Z^{2} V_{X}^{2}}$

$V_{X=\frac{S_{X}}{\bar{X}}}$

In the above formula:

$\mathrm{n}=$ number of samples

$\mathrm{N}=$ Size of all classes 
Sx $=$ Weighted average standard deviation of different classes

$\overline{\mathrm{X}}=$ Mean

$\varepsilon=$ Coefficient of error (equal to 0.02 in this study)

$\mathrm{Vx}=$ coefficient of variation

$\mathrm{Z}=$ value of confidence level

$V_{X}=0.105$

$$
n \geq \frac{\left(1.96^{2} \times \ldots\right) \times\left(0.105^{2}\right)}{\left(\_-1\right) \times\left(0.02^{2}\right)+\left(1.96^{2}\right) \times\left(0.105^{2}\right)}=
$$

Therefore, the total sample size was obtained equal to 61; but 230 subjects were considered as the sample size to ensure the confidence and reduce the sampling error.

The researcher-made questionnaire was used to collect data in quantitative phase; and most of its items were directly extracted from interview transcripts. Furthermore, the relevant specialized texts and literature were used to complete the questionnaire. The questionnaire of this research was designed and implemented according to 5-point Likert scale.

The descriptive and inferential statistics were utilized for data analysis. The descriptive statistics consisted of mean and standard deviation, minimum and maximum; and the inferential statistics used the first and second-order confirmatory factor analysis and model implementation by the help of Smart PLS3 software as well as tests by SPSS 21 software.

\section{Results}

Qualitative research data analysis

Question 1: What are the components of student life skills at primary school?

The qualitative research method and semi-structured interview with experts are applied to answer this question. Categories are as follows:

Table 1. Classification of identified codes into categories

\begin{tabular}{|c|c|}
\hline Categories & Relevant codes \\
\hline Self-awareness skills & Self-awareness \\
\hline Thinking skills & Caring, creative, and critical thinking skills \\
\hline Social skills & $\begin{array}{l}\text { Social-political skills; Familiarity with school and society regulations; } \\
\text { respect for flag; time management; social dialogue; ability to say No; } \\
\text { conversation }\end{array}$ \\
\hline Ethical skills & $\begin{array}{l}\text { Being honest and patient; interest in ethical values; respect for other } \\
\text { people; personal discipline; collective discipline; responsibility; respect } \\
\text { for privacy; right conversation }\end{array}$ \\
\hline Empathy skills & $\begin{array}{l}\text { Helping others; empathy with others; perception of other individuals' } \\
\text { emotions; empathy and kindness; Good listening and watching }\end{array}$ \\
\hline $\begin{array}{l}\text { Skills for establishing } \\
\text { effective } \\
\text { communication with } \\
\text { others }\end{array}$ & $\begin{array}{l}\text { Effective communication with others; communicational skills; skill of } \\
\text { negotiation; class dialogue; ability to establish effective relationship; } \\
\text { ways of relationship with peers, family, friends, etc; relationship with } \\
\text { students' parents }\end{array}$ \\
\hline Teamwork skills & Team and group work skills \\
\hline Life skills & $\begin{array}{l}\text { Recognition and consideration of personal hygiene; compliance with } \\
\text { safety points; conservation of environment; to have healthy mind and } \\
\text { body }\end{array}$ \\
\hline
\end{tabular}




\begin{tabular}{|c|c|}
\hline $\begin{array}{c}\text { Scientific and } \\
\text { technological skills }\end{array}$ & $\begin{array}{c}\text { Skills in application of scientific books; use of computer and electronic } \\
\text { devices; ability to listen to teachers' words; familiarity with computer; } \\
\text { methods of accountability; use of technology; use of electronic devices; } \\
\text { use of new technologies; information update; application of new } \\
\text { teaching methods; working with computer }\end{array}$ \\
\hline Problem solving skills & $\begin{array}{c}\text { Problem solving skill; questioning; asking; ability to ask question; } \\
\text { question design }\end{array}$ \\
\hline $\begin{array}{c}\text { Skills of overcoming } \\
\text { with negative emotions }\end{array}$ & $\begin{array}{c}\text { stress and anxiety control; ability to cope with emotions; coping with } \\
\text { tension; control of emotions; anger and hatred control }\end{array}$ \\
\hline Training skills & $\begin{array}{c}\text { Assignment; study technique, planning; writing technique; study skill; } \\
\text { study and education }\end{array}$ \\
\hline Decision-making skill & Decision making \\
\hline
\end{tabular}

\section{Question 2: What factors affect the student life skills?}

Table 2. Classification of identified codes into categories

\begin{tabular}{|c|c|c|}
\hline \multicolumn{2}{|c|}{ Categories } & Relevant codes \\
\hline \multirow{5}{*}{ 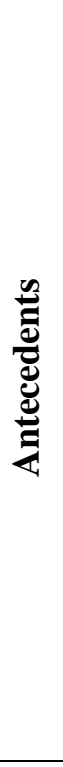 } & $\begin{array}{l}\text { Educational } \\
\text { factors }\end{array}$ & $\begin{array}{l}\text { School; Principals; assistant; classroom; teacher's teaching method; } \\
\text { textbook content; training time; school facilities; physical conditions } \\
\text { of school; school environment; changes in educational approaches; } \\
\text { changes in learning style; training innovation; teachers' strength; } \\
\text { school facilities; school management and executives; classroom } \\
\text { space; school authorities and facilities; books; training staff; teachers; } \\
\text { colleagues' relationships }\end{array}$ \\
\hline & Society & $\begin{array}{l}\text { Society, socio-political development; economic factors; media and } \\
\text { television; cultural and political conditions; society; community; } \\
\text { social conditions, citizens }\end{array}$ \\
\hline & Family & $\begin{array}{l}\text { Parents; family situation; household; parents' educational degree; } \\
\text { parents' relationship with each other and family; familial life; parents' } \\
\text { literacy; parents' cooperation; parental educational levels; parental } \\
\text { awareness }\end{array}$ \\
\hline & Peers & Friends, peers, classmates \\
\hline & $\begin{array}{l}\text { Personal } \\
\text { factors }\end{array}$ & Gender; mental growth and internal abilities; students' potential \\
\hline \multirow[t]{3}{*}{ 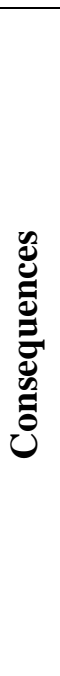 } & Educational & $\begin{array}{l}\text { Teacher's teaching method; Use of facilities; learning; use of facilities } \\
\text { by teachers; content teaching; evaluation methods; principals; } \\
\text { teachers; authorities; learning method and its purpose; evaluation } \\
\text { method and its purpose; method of content provision; evaluation } \\
\text { method; types of presentations by teachers; classroom; learning } \\
\text { environment; educational facilities; educational system; academic life; } \\
\text { teacher's teaching method; question and answer methods; role playing; } \\
\text { group discussion; lecture; career prospect; educational future; } \\
\text { students' learning method; objectives; content; educational system; } \\
\text { class control; teacher's classroom management; teaching method; goal } \\
\text { setting; content design; teaching method; evaluation }\end{array}$ \\
\hline & Behavioral & $\begin{array}{l}\text { Students' behavioral change; behavior; Students' speech; Students' } \\
\text { behavior; teacher's behavior; being a good citizen; informed citizen }\end{array}$ \\
\hline & Policy making & $\begin{array}{c}\text { Policy making; planning; determination and design of goals; dominant } \\
\text { philosophy of educational system }\end{array}$ \\
\hline
\end{tabular}

From the perspective of experts, self-awareness, thinking skills, social and ethical skills, empathy, effective communication with others, teamwork skills, life skills, scientific and technological skills, problem solving skills, coping with negative emotions, educational skills, 
and decision-making skills are among the life skills components at primary school. They also believe that the educational factors, community, family, peers and personal factors affect the student life skills through educational, behavioral and policy-making aspects.

\section{Extracted model from qualitative data}

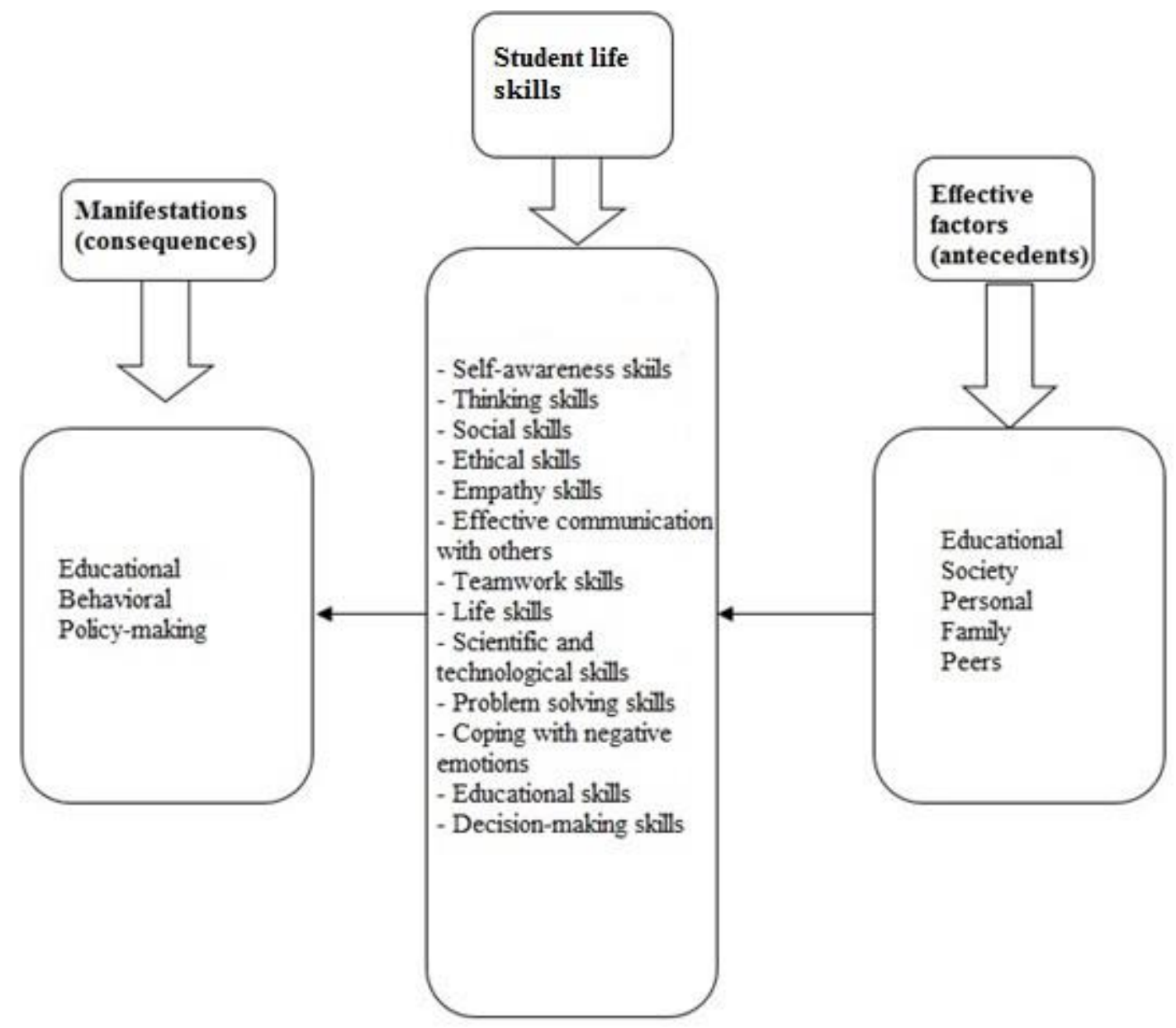

Figure 1. Extracted model from qualitative data

\section{Quantitative results}

\section{Study of data normality}

According to normality test of research variables, the research variables have free distribution with regard to Kolmogorov-Smirnov statistics at the level of $p<0.05$ for all variables related to student life skills, antecedents and consequences of student life skills and variables associated with educational tasks; hence, the non-parametric tests are used to examine variables.

\section{Evaluation of measurement model for student life skills}

According to researchers, the measurement model is homogeneous if the absolute value of factor loading for each observable variable corresponding to the latent variable of that model, is greater than 0.7. However, this value is acceptable if the factor loading is higher than 0.4 and the AVE is also higher than 0.5. In this regard, all items related to the student life skills as the latent variable have factor loadings of higher than 0.4; so none of the items will be removed. 


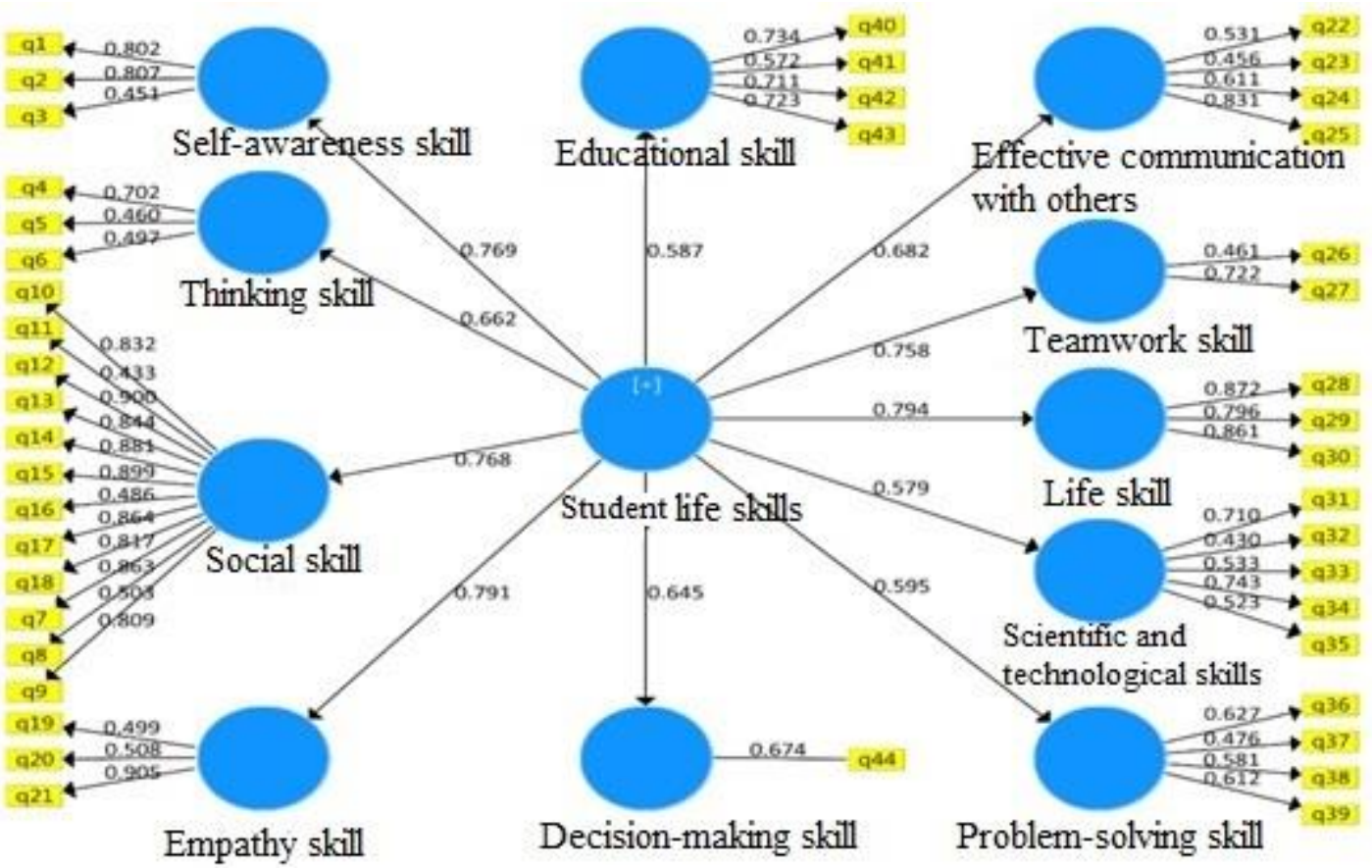

Figure 2. Smart-PLS Software output for measurement model related to student life skills

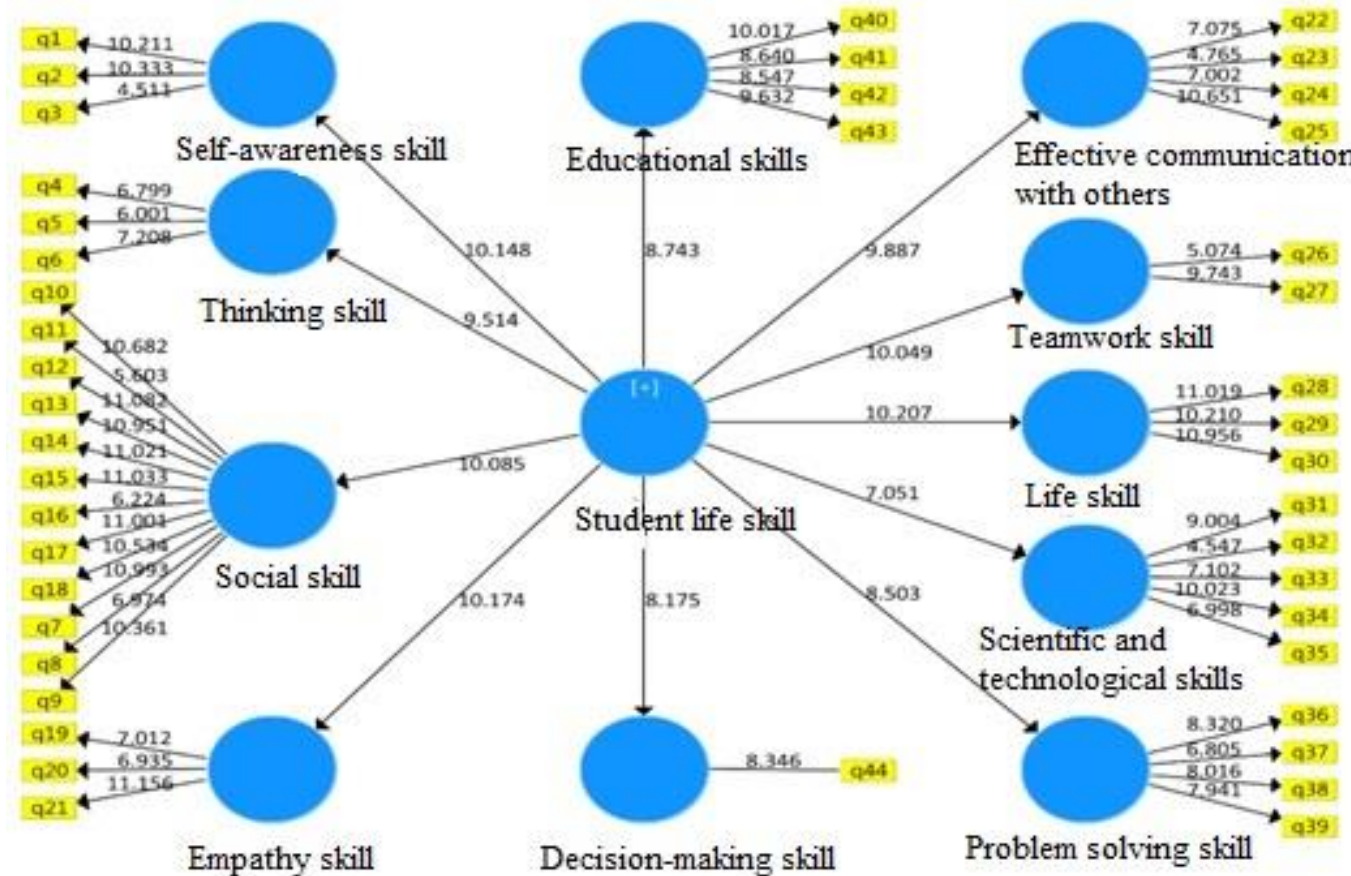

Figure 3. T-scores for factor loadings of measurement model of student life skills

\section{First order confirmatory factor analysis}

In the confirmatory factor analysis, it is necessary to study the construct validity in order to determine whether the selected indicators for measurement of target constructs have necessary accuracy.

Validity test

All items have proper factor loadings on their own latent variables; and these factor loadings are significant according to t-score at the level of 0.05 . In other words, the t-value corresponding to each factor loading is greater than its critical value (1.96) at the level of 0.05 . 
Therefore, these indicators have necessary accuracy for measuring their constructs, so they entered the final analysis.

Convergent and divergent validity is used to study the validity of measurement model.

The average variance extracted (AVE) is used to study the convergent validity. The amount of this index should be higher than 0.50 , and since it is higher than 0.50 for all variables of this research, the measurement model of student life skills has appropriate convergent validity.

Fornell-Larcker criterion is used to study the diagnostic or divergent validity of measurement model in Smart-PLS software. According to this index, the square root of Average Variance Extracted (ÖAVE) for any latent variable should be greater than the maximum correlation of that latent variable with other latent variables. Furthermore, the square root of average variance extracted for any latent variable should be higher than the maximum correlation of that latent variable with other latent variables indicating that the diagnostic validity of measurement model is appropriate.

\section{Reliability test}

The composite reliability and Cronbach's alpha are used to study the reliability of model. The values of these two criteria should be higher than 0.70 .

Table 3. Composite reliability and Cronbach's alpha values for measurement model of student life skills

\begin{tabular}{|c|c|c|}
\hline Student life skills & Composite reliability & Cronbach's alpha \\
\hline Self-awareness skills & 0.885 & 0.751 \\
\hline Thinking skills & 0.807 & 0.829 \\
\hline Social skill & 0.895 & 0.834 \\
\hline Empathy skill & 0.893 & 0.799 \\
\hline $\begin{array}{c}\text { Effective communication with } \\
\text { others }\end{array}$ & 0.890 & 0.830 \\
\hline Teamwork skills & 0.823 & 0.829 \\
\hline Life skill & 0.867 & 0.770 \\
\hline Scientific and technological skills & 0.812 & 0.817 \\
\hline Problem-solving skills & 0.882 & 0.804 \\
\hline Educational skills & 0.858 & 0.890 \\
\hline Decision-making skill & 0.898 & 0.833 \\
\hline
\end{tabular}

As shown in the table above, the composite reliability (Dillon-Goldstein's p) and Cronbach's alpha of all variables related to student life skills are approved in the measurement model.

\section{Second-order confirmatory factor analysis}

Second-order factor model is defined as a type of factor models in which the latent factors measuring by observed variables are under the influence of a more fundamental variable called the latent variable, but they are at a higher level. In this model, each of the components can be used as the indicators or aspects of student life skills.

Table 4. Results of second-order confirmatory factor analysis for student life skills

\begin{tabular}{|c|c|c|c|}
\hline Constructs & $\begin{array}{c}\text { Factor } \\
\text { loading }\end{array}$ & t-value & $\begin{array}{c}\text { Significance } \\
\text { level }\end{array}$ \\
\hline Self-awareness skills & 0.769 & 10.148 & 0.000 \\
\hline Thinking skills & 0.662 & 9.514 & 0.000 \\
\hline Social skill & 0.768 & 10.085 & 0.000 \\
\hline Empathy skill & 0.791 & 10.174 & 0.000 \\
\hline Effective communication with others & 0.682 & 9.887 & 0.000 \\
\hline Teamwork skills & 0.758 & 10.049 & 0.000 \\
\hline Life skill & 0.794 & 10.207 & 0.000 \\
\hline Scientific and technological skills & 0.579 & 7.051 & 0.000 \\
\hline Problem-solving skills & 0.595 & 8.503 & 0.000 \\
\hline
\end{tabular}




\begin{tabular}{|c|c|c|c|}
\hline Educational skills & 0.587 & 8.743 & 0.000 \\
\hline Decision-making skill & 0.674 & 8.346 & 0.000 \\
\hline AVE & \multicolumn{3}{|c|}{0.698} \\
\hline c $\rho$ & \multicolumn{3}{|c|}{0.900} \\
\hline$\alpha$ & \multicolumn{3}{|c|}{0.864} \\
\hline
\end{tabular}

As shown in the table above, the values of factor loading are desirable in the second-order factor analysis. On the other hand, t-value corresponding to each factor loading is greater than its critical value (1.96) and significant at the level of 0.05 . Furthermore, the values of composite reliability and Cronbach's alpha are respectively equal to 0.900 and 0.864 indicating the high internal consistency of variables. The AVE value is also equal to 0.698 which is higher than 0.05 , and thus the convergent validity of model is confirmed.

\section{Evaluation of measurement model related to antecedents and consequences of student life} skills

According to researchers, the measurement model is homogeneous if the absolute value of factor loading for each observable variable corresponding to the latent variable of that model, is greater than 0.7. The acceptable factor loading is considered equal to 0.4 in this research. However, this value is acceptable if the factor loading is higher than 0.4 and the AVE is also higher than 0.5. In this regard, all items related to the antecedents and consequences of student life skills as the latent variable have factor loadings of higher than 0.4 ; so none of the items will be removed.

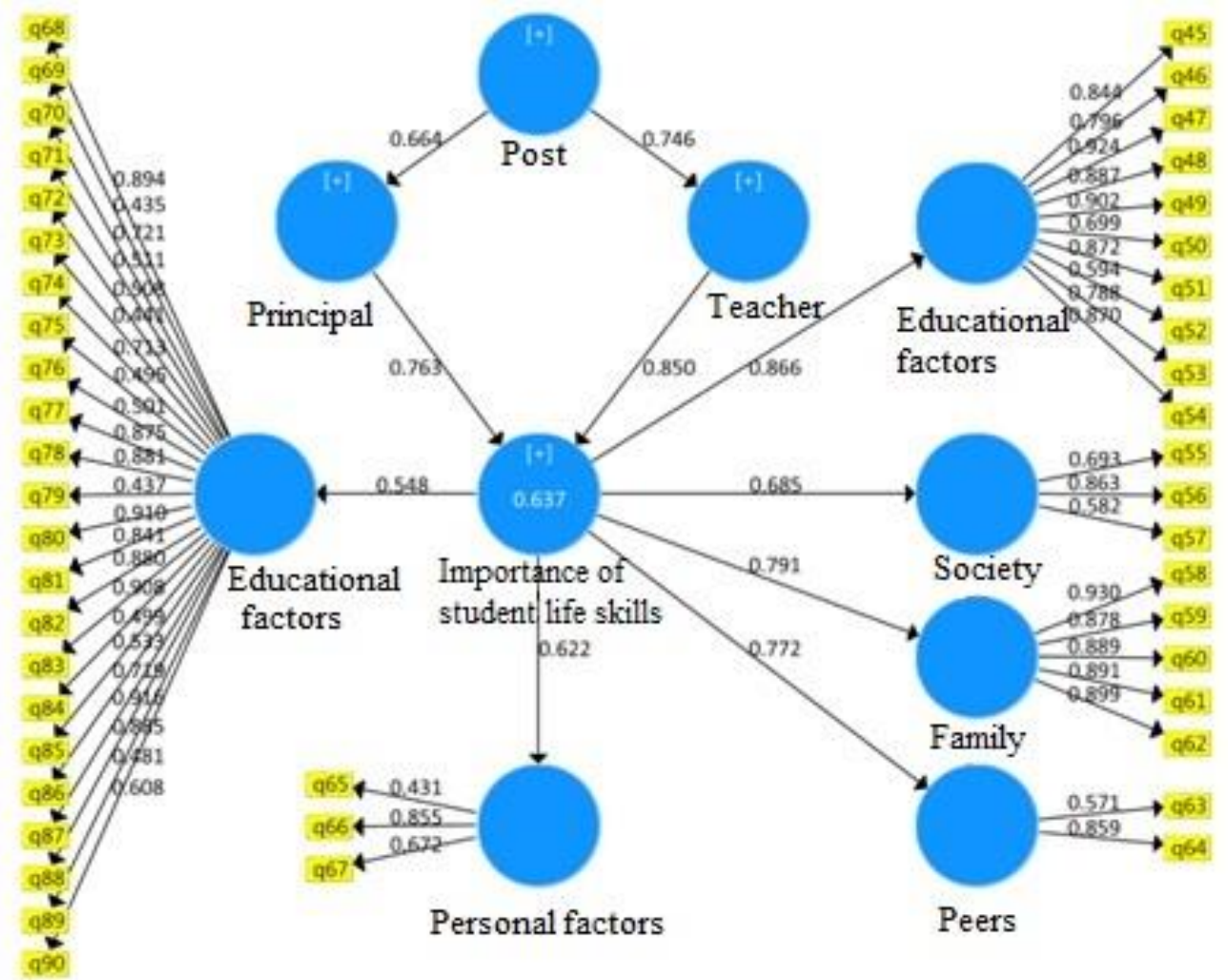

Figure 4. Smart- PLS Software output for measurement model related to the antecedents and consequences of student life skills 


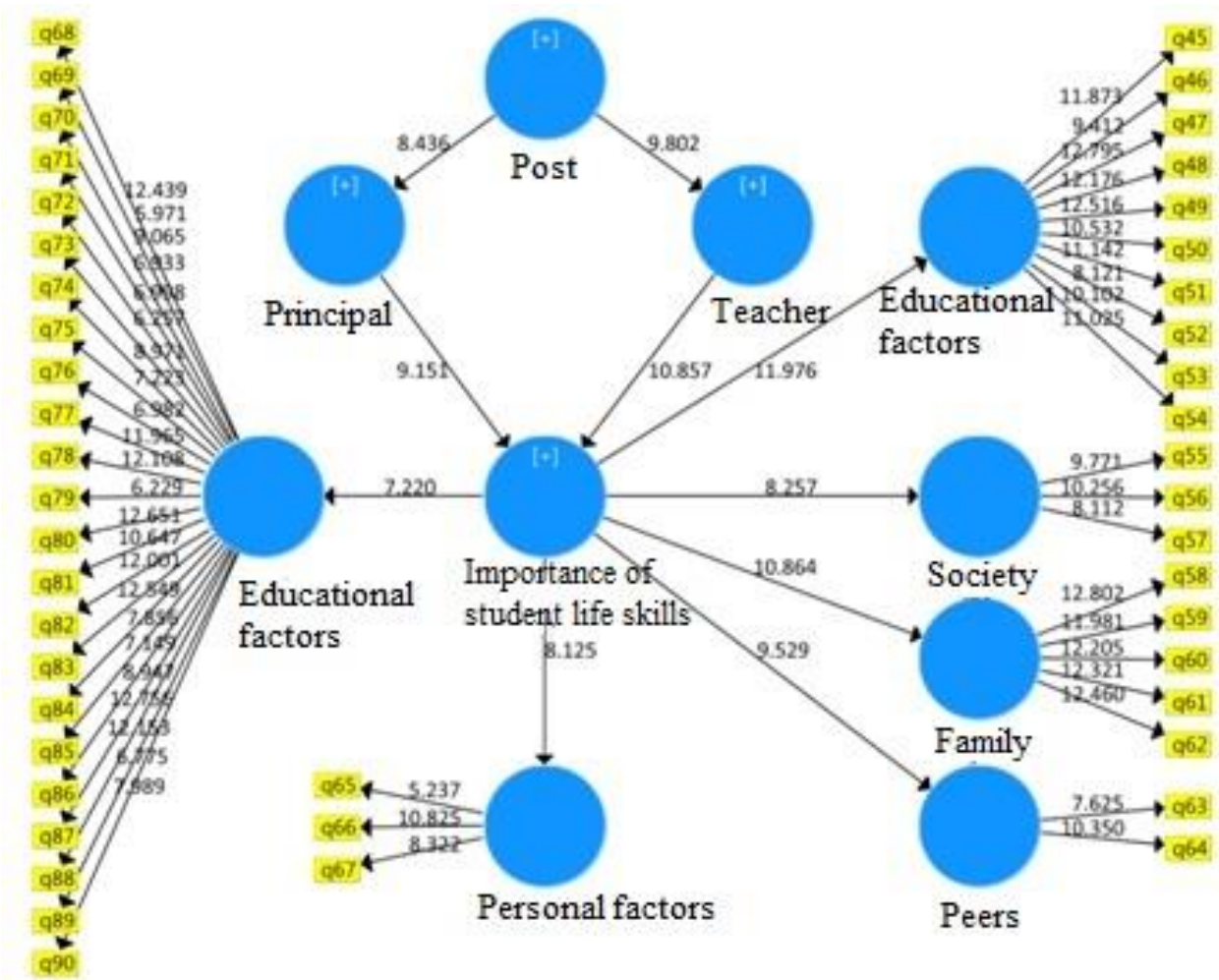

\section{Figure 5. T-scores related to the factor loadings of measurement model for antecedents and consequences of student life skills}

\section{First-order confirmatory factor analysis}

The construct validity should be first studied in confirmatory factor analysis in order to determine whether the selected indicators for measuring desired constructs are accurate. All items have proper factor loadings on their own latent variables; and these factor loadings are significant at the level of 0.05 due the $t$-score. In other words, the $t$-value corresponding to each factor loading is greater than its critical value (1.96) at the level of 0.05. As a result, these indicators have necessary accuracy for measuring their relevant constructs, so they are included in the final analysis.

The average variance extracted (AVE) is used to study the convergent validity. The value of this index should be higher than 0.50 , and since it is higher than 0.50 for all variables of this research, the measurement model for antecedents and consequences of student life skills has appropriate convergent validity.

Fornell-Larcker criterion is used to study the diagnostic or divergent validity of measurement model in Smart-PLS software. According to this index, the square root of Average Variance Extracted (ÖAVE) for any latent variable should be greater than the maximum correlation of that latent variable with other latent variables indicating that the diagnostic validity of measurement model is appropriate.

\section{Reliability test}

The composite reliability and Cronbach's alpha are used to study the reliability of model. The values of these two criteria should be higher than 0.70 . 
Table 5.Composite reliability and Cronbach's alpha values for measurement model of antecedents and consequences of student life skills

\begin{tabular}{|c|c|c|}
\hline $\begin{array}{c}\text { Antecedents and consequences } \\
\text { of student life skills }\end{array}$ & Composite reliability & Cronbach's alpha \\
\hline Educational skills & 0.875 & 0.894 \\
\hline Society & 0.866 & 0.786 \\
\hline Family & 0.859 & 0.780 \\
\hline Peers & 0.893 & 0.839 \\
\hline Personal factors & 0.881 & 0.821 \\
\hline Educational factors & 0.879 & 0.890 \\
\hline
\end{tabular}

As shown in the table above, the composite reliability (Dillon-Goldstein's p) and Cronbach's alpha of all variables related to antecedents and consequences of student life skills are approved in the measurement model.

\section{Second-order confirmatory factor analysis}

Second-order factor model is defined as a type of factor models in which the latent factors measuring by observed variables are under the influence of a more fundamental variable called the latent variable, but they are at a higher level. In this model, each of the components can be used as the indicators or antecedents and consequences of student life skills.

Table 6. Results of second-order confirmatory factor analysis for antecedents and consequences of student life skills

\begin{tabular}{|c|c|c|c|}
\hline Constructs & $\begin{array}{c}\text { Factor } \\
\text { loading }\end{array}$ & t-value & $\begin{array}{c}\text { Significance } \\
\text { level }\end{array}$ \\
\hline Educational factors & 0.866 & 11.976 & 0.000 \\
\hline Society & 0.685 & 8.257 & 0.000 \\
\hline Family & 0.791 & 10.864 & 0.000 \\
\hline Peers & 0.772 & 9.529 & 0.000 \\
\hline Personal factors & 0.622 & 8.125 & 0.000 \\
\hline Educational factors & 0.548 & 7.220 & 0.000 \\
\hline AVE & \multicolumn{3}{|c|}{0.590} \\
\hline$c \rho$ & 0.856 \\
\hline$\alpha$ & 0.823 \\
\hline
\end{tabular}

As shown in the table above, the values of factor loading are desirable in the second-order factor analysis. On the other hand, t-value corresponding to each factor loading is greater than its critical value (1.96) and significant at the level of 0.05 . Furthermore, the values of composite reliability and Cronbach's alpha are respectively equal to 0.823 and 0.856 indicating the high internal consistency of variables. The AVE value is also equal to 0.590 which is higher than 0.05 , and thus the convergent validity of model is confirmed.

\section{Evaluation of measurement model related to educational tasks}

According to researchers, the measurement model is homogeneous if the absolute value of factor loading for each observable variable corresponding to the latent variable of that model, is greater than 0.7. The acceptable factor loading is considered equal to 0.4 in this research. However, this value is acceptable if the factor loading is higher than 0.4 and the AVE is also higher than 0.5. In this regard, all items related to the educational tasks as the latent variable have factor loadings of higher than 0.4 ; so none of the items will be removed. 


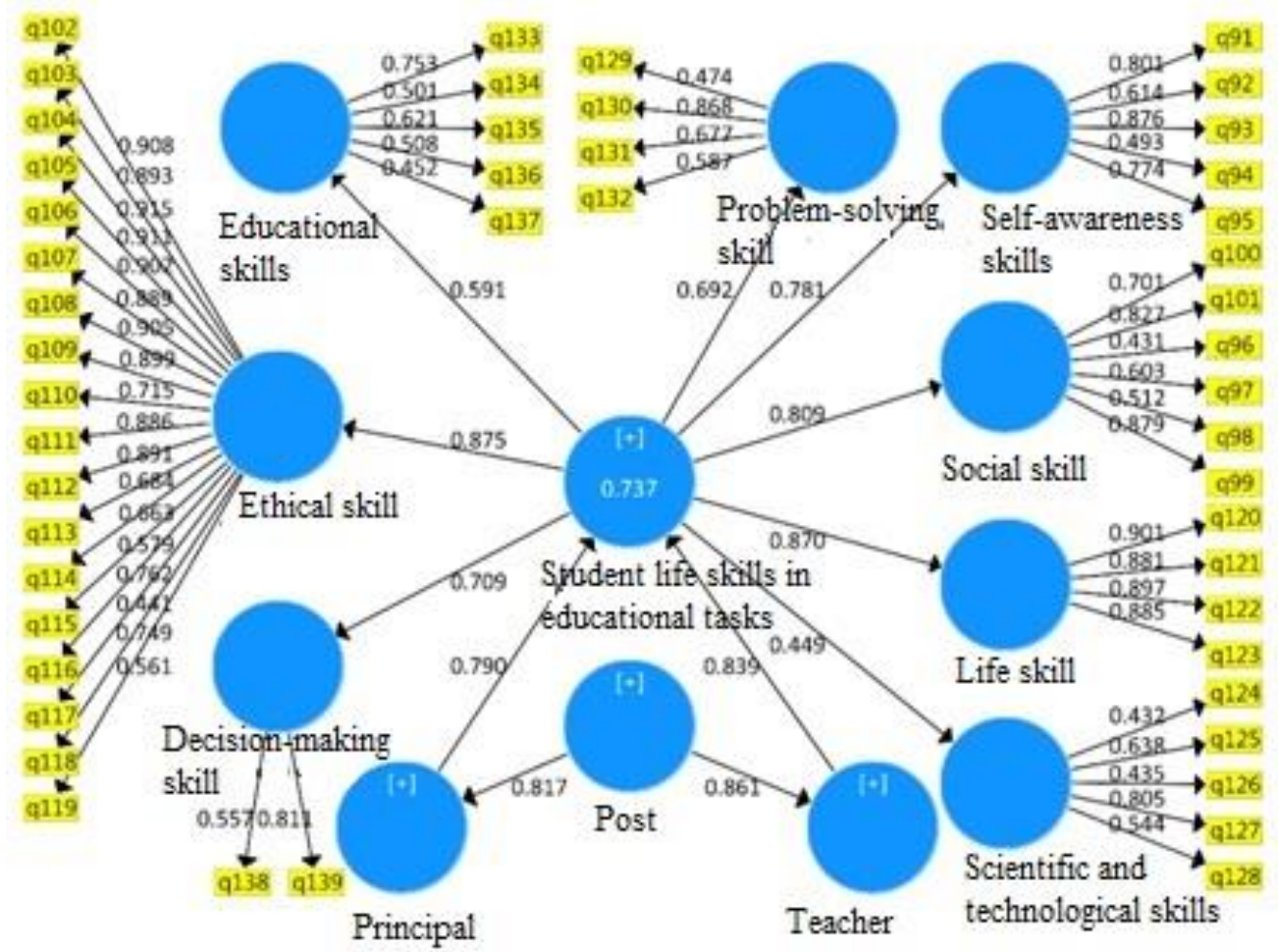

Figure 6. Smart- PLS Software output for measurement model related to the educational

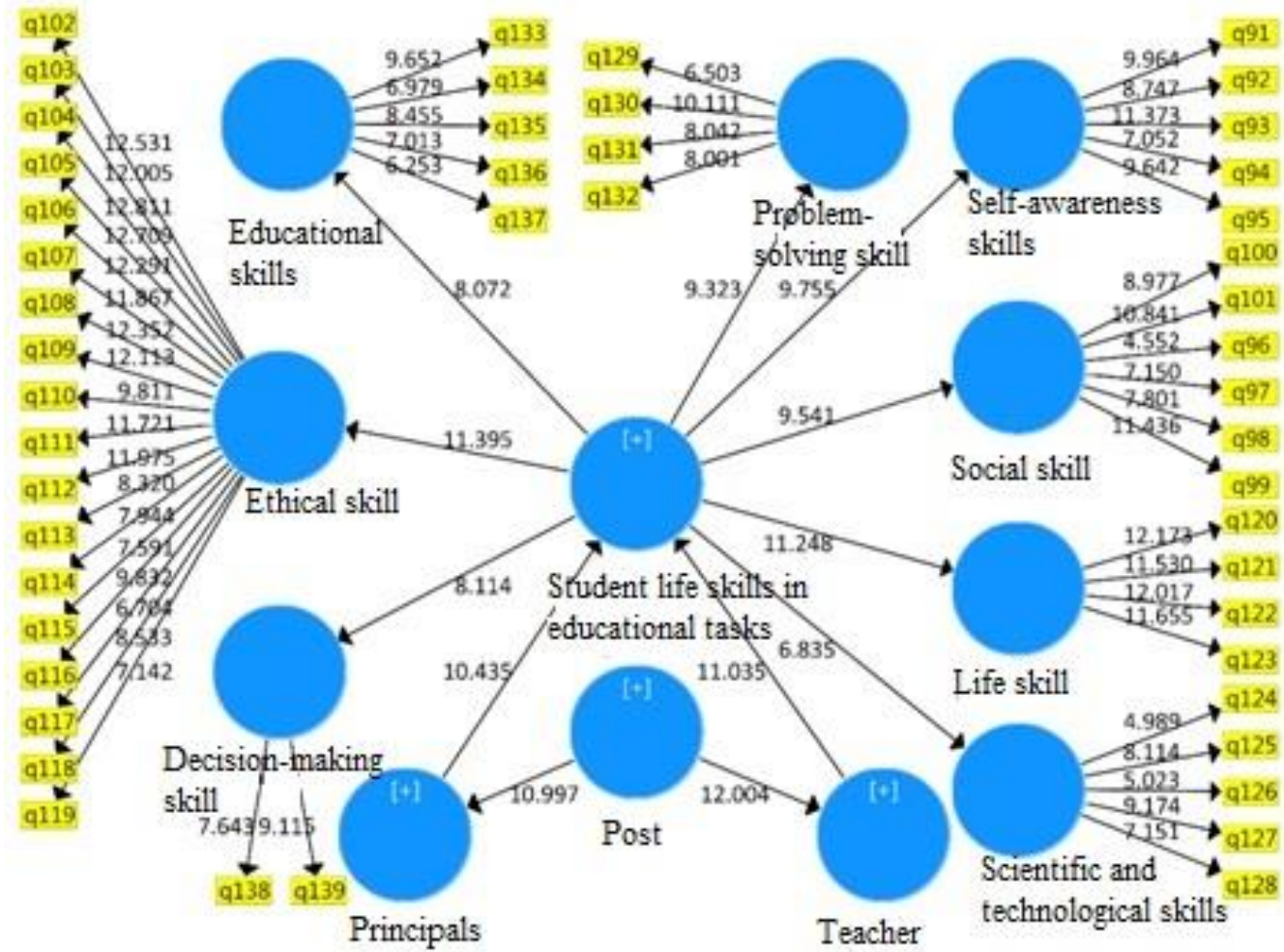

Figure 7. T-scores related to the factor loadings of measurement model for educational tasks

First-order confirmatory factor analysis

The construct validity should be first studied in confirmatory factor analysis in order to determine whether the selected indicators for measuring desired constructs are accurate. All items have proper factor loadings on their own latent variables; and these factor loadings are significant 
at the level of 0.05 due the $t$-score. In other words, the t-value corresponding to each factor loading is greater than its critical value (1.96) at the level of 0.05 . As a result, these indicators have necessary accuracy for measuring their relevant constructs, so they are included in the final analysis.

\section{Reliability test}

The composite reliability and Cronbach's alpha are used to study the reliability of model. The values of these two criteria should be higher than 0.70 .

Table 7. Composite reliability and Cronbach's alpha values for measurement model of educational tasks

\begin{tabular}{|c|c|c|}
\hline Educational tasks & Composite reliability & Cronbach's alpha \\
\hline Self-awareness & 0.773 & 0.810 \\
\hline Social skill & 0.882 & 0.993 \\
\hline Ethical skill & 0.856 & 0.675 \\
\hline Life skill & 0.774 & 0.662 \\
\hline Scientific and technological skills & 0.834 & 0.664 \\
\hline Problem-solving skill & 0.789 & 0.670 \\
\hline Educational skill & 0.905 & 0.670 \\
\hline Decision-making skill & 0.523 & 0.844 \\
\hline
\end{tabular}

As shown in the table above, the composite reliability (Dillon-Goldstein's p) and Cronbach's alpha of all variables related to educational tasks are approved in the measurement model.

\section{Validity test}

Convergent and divergent validity is used to study the validity of measurement model.

The average variance extracted (AVE) is used to study the convergent validity. The amount of this index should be higher than 0.50 , and since it is higher than 0.50 for all variables of this research, the measurement model of educational tasks has appropriate convergent validity.

Fornell-Larcker criterion is used to study the diagnostic or divergent validity of measurement model in Smart-PLS software. According to this index, the square root of Average Variance Extracted (ÖAVE) for any latent variable should be greater than the maximum correlation of that latent variable with other latent variables indicating that the diagnostic validity of measurement model is appropriate.

\section{Second-order confirmatory factor analysis}

Second-order factor model is defined as a type of factor models in which the latent factors measuring by observed variables are under the influence of a more fundamental variable called the latent variable, but they are at a higher level. In this model, each of the components can be used as the indicators or educational tasks.

Table 8. Results of second-order confirmatory factor analysis for educational tasks

\begin{tabular}{|c|c|c|c|}
\hline Constructs & $\begin{array}{c}\text { Factor } \\
\text { loading }\end{array}$ & t-value & $\begin{array}{c}\text { Significance } \\
\text { level }\end{array}$ \\
\hline Self-awareness & 0.781 & 9.755 & 0.000 \\
\hline Social skill & 0.809 & 9.541 & 0.000 \\
\hline Ethical skill & 0.875 & 11.395 & 0.000 \\
\hline Life skill & 0.870 & 11.248 & 0.000 \\
\hline Scientific and technological skills & 0.449 & 6.835 & 0.000 \\
\hline Problem-solving skill & 0.692 & 9.323 & 0.000 \\
\hline Educational skill & 0.591 & 8.072 & 0.000 \\
\hline Decision-making skill & 0.709 & 8.114 & 0.000 \\
\hline AVE & \multicolumn{3}{|c|}{0.542} \\
\hline c $\rho$ & 0.910 \\
\hline$\alpha$ & \multicolumn{3}{|l}{} \\
\hline
\end{tabular}


As shown in the table above, the values of factor loading are desirable in the second-order factor analysis. On the other hand, t-value corresponding to each factor loading is greater than its critical value (1.96) and significant at the level of 0.05 . Furthermore, the values of composite reliability and Cronbach's alpha are respectively equal to 0.910 and 0.895 indicating the high internal consistency of variables. The AVE value is also equal to 0.542 which is higher than 0.05 , and thus the convergent validity of model is confirmed.

\section{Discussion and Conclusion}

Given the importance of life skills to deal with daily life problems and the impact of relevant education on the health, mental health, academic achievement and generally the personal and social life improvement as well as the important roles of schools in preventing the social damages, learning and improvement of mental health, there is a need for attention to education process. The life skills have been changed into the totally human skills as a bridge between human and society and a system output in educational system of Iran. The researchers have been thinking about where the functions of these skills can be seen because it is very difficult to measure them.

It seems that the research on the student life skills has paid special attention to social functions, but it has not paid any attention to skills which develop the educational characteristics, learning health, and reduce the cost of teaching-learning process. These skills exist in latent but effective forms at schools, but teachers and principals are not educated in this field.

A lot of students are prone to anxiety and some of them are faced with or suffering from a variety of mental diseases and consequently they are unable to solve problems, trapped in drug consumption, and are willing to suicide. These disorders will lead to the failure in performance at school, education and family, and finally it may lead to the academic failure and expulsion from school and criminal behavior which will be the causes of long-term consequences for them. It will be useful to cope with these problems by resources and skills which help us to solve our problems by the best possible way, but unfortunately there is a gap in the educational system of Iran as it has been limited to provision of information and promotion of students' knowledge, but it has not taken any continuous and inclusive effort to deal with the adulthood challenges and requirement. Moreover, the conducted studies suggest that the life skills training has not been seriously considered in practice; and the students' levels of life skills achievement indicate the teachers' familiarity with skills, and its deficiency or absence.

\section{References}

Atilgan E. (2013). The Effect of Communication Skills and Interpersonal Problem Solving Skills on Social Self-Efficacy, Educational Sciences: Theory \& Practice, 13(2), 739-745

Esmaeilzadeh, Ali-Asghar. (2012). Study on the approaches and procedures of life skills training in several countries, and provision of comparable experiences. Tehran: ACECR, teacher training branch. Office of writing and editing textbooks, Ministry of Education.

Frank; L., Kleinman, L., Rent, A, Cielsa, G., Kim, J. J., \& Zacker, C. (2006). Health related quality of life associated with irritable bowel syndrome: Comparison with other chronic diseases. Clinical Therapeutics, 24, 675-689.

Hulya, S.B. (2013). Social emotional learning skills and life satisfaction, International Journal on new trend in education and their implications, 4; 283-295.

Kala, S. Isaramali, S \&. Pohthong, A. (2010). Electronic learning and constructivism: A model for nursing education. Nurse Education Today, 30, 61-66.

Kallio, E. \& Y. Wells. (2012). Systematic constructivism applied to higher education in psychology. Book-review: Mayo 'Constructing Undergraduate Psychology Curricula. Promoting authentic learning and Assessment in the Teaching of Psychology'.

Kharrazi, K., \& Khareshki, H. (2010). Self-regulated learning: The role of environmental perceptions and motivational beliefs. Psychological Reports, 107(1), 303-317.

Mangrulkar. M, Vince.CH, Posner. M. (2001). Life skills approach to child and adolescent healthy human development, Swedish, W.K. Kellogy foundation.

Orkin. W. (1998). Improving student life skills through classroom intervention and integration 
Ramesht, Maryam; and Farshad, Siamak. (2004). Study on the effect of life skills training on the prevention of drug abuse in students; the Second National Seminar on students' mental health,

Sandhu, R. (2014). A Study of Life Skills of Pupil Teachers. Indian Journal of Fundamental and Applied Life Sciences, 4(3); 389-395

Shechtman, Z; Levy, M and Leichtentritt, J. (2005). Impact of Life Skills Training on Teachers' Perceived Environment and Self-Efficacy, Journal of Educational Research,98(3), 144

Sreehari Ravindranath, R.; Thomas .J and Shareef .A (2012). Importance of Life Skills Training for Corporate Sector, Bonfring International Journal of Industrial Engineering and Management Science, 2(3), 5-7.

Turner, N.E., Macdonald, J. and Somerset, M. (2008). Life Skills, Mathematic All Reasoning and Critical Thinking: Curricula for Prevention of Problem Gambling. Journal of Gambling Studies, 24, 27-29.

World Health Organization (WHO). (2006). Life skills training program. Translation: Robabeh Nouri-Ghassemabadi; and Parvaneh Mohammadkhani, Tehran: Department of Cultural Affairs and Prevention of Welfare Organization of Iran. 